\title{
Self-Assembly of Cluster-Based Nanoscopic Supramolecules into One-Dimensional Coordination Polymers
}

\author{
Jian-Jun Zhang, Sergio Aarón Gamboa, Barry Julian Davis, and Abdessadek Lachgar \\ Department of Chemistry, Wake Forest University, Winston-Salem, NC 27109, USA \\ Correspondence should be addressed to Abdessadek Lachgar, lachgar@wfu.edu
}

Received 15 April 2009; Revised 9 July 2009; Accepted 10 July 2009

Recommended by Sridhar Komarneni

Octahedral metal clusters $\left[\mathrm{Nb}_{6} \mathrm{Cl}_{12}(\mathrm{CN})_{6}\right]^{4-},(\mathrm{Mn}(\text { Salen }))^{+}\left(\right.$or $\left.(\mathrm{Mn}(7-\mathrm{MeSalen}))^{+}\right)\left(\right.$Salen $=N, N^{\prime}$-ethylene-bis- $($ salicylidene)iminate) and ditopic organic linkers (4, $4^{\prime}$-bpe (trans-1, 2-bis(4-pyridyl)-ethylene) or 4, $4^{\prime}$-dpyo (4, $4^{\prime}$-dipyridyl $N, N^{\prime}$-dioxide) ) self-assemble to form three cluster-based 1D coordination polymers: $\left[\mathrm{Mn}(\mathrm{Salen})(\mathrm{MeOH})_{2}\right]_{2}\left\{\left(4,4^{\prime}-d p y o\right)\right.$ $\left.\left[(\mathrm{Mn}(\text { Salen }))_{2}\left(\mathrm{Nb}_{6} \mathrm{Cl}_{12}(\mathrm{CN})_{6}\right)\right]\right\} \quad \cdot 2 \mathrm{MeOH} \quad(\mathbf{1}), \quad\left\{\left(4,4^{\prime}\right.\right.$-bpe $\left.)\left[(\mathrm{Mn}(7-\mathrm{MeSalen}))_{2}\left(\mathrm{Mn}(7-\mathrm{MeSalen})\left(\mathrm{H}_{2} \mathrm{O}\right)\right)_{2}\left(\mathrm{Nb}_{6} \mathrm{Cl}_{12}(\mathrm{CN})_{6}\right)\right]\right\}$. $1.5 \mathrm{MeCN} \cdot 8 \mathrm{H}_{2} \mathrm{O}(2)$, and $\left[\left(4,4^{\prime}-\right.\right.$ bpe $\left.)\left(\mathrm{Mn}(\text { Salen })\left(\mathrm{H}_{2} \mathrm{O}\right)\right)_{2}\right]\left\{\left(4,4^{\prime}-\text { bpe }\right)_{2}\left[(\mathrm{Mn}(\text { Salen })(\mathrm{MeOH}))_{2}(\mathrm{Mn}(\text { Salen }))_{2}\left(\mathrm{Nb}_{6} \mathrm{Cl}_{12}(\mathrm{CN})_{6}\right)\right]\right.$ $\left.\left[(\mathrm{Mn}(\text { Salen }))_{2}\left(\mathrm{Nb}_{6} \mathrm{Cl}_{12}(\mathrm{CN})_{6}\right)\right]\right\} \cdot 16 \mathrm{H}_{2} \mathrm{O}(3)$. Single crystal X-ray diffraction analyses show that the frameworks of the three coordination polymers are built of heterotrimeric and/or heteropentameric supramolecular species linked by ditopic organic ligands. The framework of 1 consists of anionic chains built of heterotrimeric dianions $\left[(\mathrm{Mn}(\mathrm{Salen}))_{2}\left(\mathrm{Nb}_{6} \mathrm{Cl}_{12}(\mathrm{CN})_{6}\right)\right]^{2-}$ (T) linked by $4,4^{\prime}-d p y o$. The chains run along two directions $\left(\left[\begin{array}{lll}0 & 2 & -2\end{array}\right]\right.$ and $\left.\left[\begin{array}{lll}0 & 3 & 3\end{array}\right]\right)$ leading to the formation of channels along the crystallographic (a) direction where the cations $\left[\operatorname{Mn}(\operatorname{Salen})(\mathrm{S})_{2}\right]^{+}$and solvent molecules are located. Also, 2 was reported earlier, it possesses a neutral 1D chain built of neutral heterpentameric supramolecules: $\left[(\mathrm{Mn}(7-\mathrm{MeSalen}))_{2}(\mathrm{Mn}(7-\mathrm{MeSalen})(\mathrm{S}))_{2}\left(\mathrm{Nb}_{6} \mathrm{Cl}_{12}(\mathrm{CN})_{6}\right)\right]$ (P) linked by 4, 4'-bpe ligands. Hydrogen bonds between nonbridging cyanide ligands and coordinated solvent molecules connect the chains into 2D hydrogen-bonded frameworks. Finally, 3 features an anionic chain, built of alternating heterotrimers $\left[(\mathrm{Mn}(\operatorname{Salen}))_{2}\left(\mathrm{Nb}_{6} \mathrm{Cl}_{12}(\mathrm{CN})_{6}\right)\right]^{2-}$ and heteropentamers $\left[(\mathrm{Mn}(\text { Salen })(\mathrm{S}))_{2}(\mathrm{Mn}(\text { Salen }))_{2}\left(\mathrm{Nb}_{6} \mathrm{Cl}_{12}(\mathrm{CN})_{6}\right)\right]$ linked by the organic spacer $4,4^{\prime}$ - bpe. The anionic charge is compensated by the in situe-assembled $\left[\mathrm{Mn}(\text { Salen })(\mathrm{S})\left(4,4^{\prime} \text {-bpe }\right) \mathrm{Mn}(\text { Salen })(\mathrm{S})\right]^{2+}$ dimers. Magnetic measurements reveal that the Mn(III) ions are well isolated and only weak magnetic interactions are observed. The thermal stability of the three compounds was investigated.

Copyright (c) 2009 Jian-Jun Zhang et al. This is an open access article distributed under the Creative Commons Attribution License, which permits unrestricted use, distribution, and reproduction in any medium, provided the original work is properly cited.

\section{Introduction}

Hybrid inorganic-organic materials, coordination polymers, and metal organic frameworks have received considerable attention in recent years [1-8]. These materials generally possess polymeric structures based on metal ions connected through inorganic and/or organic bridging ligands $[9,10]$. The topology and function of these materials can, in principle, be controlled through judicious choice of their molecular components. A number of metal-organic frameworks (MOFs) have been prepared and are being actively investigated for their potential use in gas storage [11-16], catalysis $[17,18]$, magnetic materials [19-21], electronics, and optics [22-25]. The initial work focused on the use of single metal atoms as nodes, and quickly evolved toward the use of polynuclear metal complexes and metal clusters containing metal-metal bonds as nodes [26-29].

Octahedral face-capped $\mathrm{M}_{6} \mathrm{~L}_{8}^{i} \mathrm{~L}_{6}^{a}$ (M are metals of Groups 6 and 7; $\mathrm{L}^{i}=$ halide, chalocogenide) or edge-capped $\mathrm{M}_{6} \mathrm{~L}_{12}^{i} \mathrm{~L}_{6}^{a}$ ( $\mathrm{M}$ are metals from Groups 4 and 5) clusters are characterized by their variety of electronic states and interesting properties arising from the metal-metal bonds [30-33]. The most prominent series of cluster compounds are the Chevrel-Sergent phases, which exhibit superconductivity at high critical magnetic fields, catalytic activity, and good characteristics as solid-state electrode materials [34-38]. However, $\mathrm{M}_{6} \mathrm{~L}_{8}^{i}$ or $\mathrm{M}_{6} \mathrm{~L}_{12}^{i}$ inner core has an atom- or ion-like behavior, is stable in solution, and can be subjected to a variety of ligand substitution reactions. The cyanosubstituted hexanuclear clusters are analogous to hexacyanometallates 
and are being studied as building blocks for diverse structural assemblies ranging from discrete supramolecular assemblies to polymeric frameworks [39-70].

Manganese(III) complexes with tetradentate Salen-type Schiff-base ligands $[\mathrm{Mn}(\mathrm{Ls})]^{+}$have been widely used as functional units for the preparation of 1D magnetic coordination polymers due to the availability of two axial coordination sites at about $180^{\circ}$ from each other, and magnetic anisotropy of the $\mathrm{d}^{4} \mathrm{Mn}^{3+}$ ions [71-75]. These complexes have been used to prepare cluster-based materials in which the complex directs the assembly of metal clusters into supramolecular assemblies by acting as bridging metal ligand. Moreover, some $[\mathrm{Mn}(\mathrm{Ls})]^{+}$complexes are used as efficient homogeneous catalysts for the conversion of achiral olefins into chiral epoxides, thence their inclusion as building blocks of solids can potentially lead to novel heterogeneous catalysts [76].

We have previously reported that reactions between $\left[\mathrm{Nb}_{6} \mathrm{Cl}_{12}(\mathrm{CN})_{6}\right]^{4-}$ and $[\mathrm{Mn}(\mathrm{L})]^{+}$complexes result in the assembly of supramolecular species in which the cluster is coordinated by $1,2,3,4$, or 6 metal complexes [66]. As the number of metal complexes per cluster increases, the charge and size of these functionalized nanosized molecules increases (Table 1).

Here, we show that some of these supramolecules can be used as building blocks for the assembly of 1D coordination polymers. Thus, the heterotrimeric dianions $\left[(\mathrm{Mn}(\text { Salen }))_{2}\left(\mathrm{Nb}_{6} \mathrm{Cl}_{12}(\mathrm{CN})_{6}\right)\right]^{2-}$ have been connected via $4,4^{\prime}-d p y o$ to form an anionic $1 \mathrm{D}$ coordination polymer $\left[\mathrm{Mn}(\text { Salen })(\mathrm{MeOH})_{2}\right]_{2}\left\{\left(4,4^{\prime}\right.\right.$-dpyo $)\left[(\mathrm{Mn}(\text { Salen }))_{2}\right.$ $\left.\left.\left(\mathrm{Nb}_{6} \mathrm{Cl}_{12}(\mathrm{CN})_{6}\right)\right]\right\} \cdot 2 \mathrm{MeOH}(\mathbf{1})$. The neutral heteropentamers have been assembled into neutral $1 \mathrm{D}$ coordination polymers $\left\{\left(4,4^{\prime}\right.\right.$-bpe $)\left[(\mathrm{Mn}(7-\mathrm{MeSalen}))_{2}(\mathrm{Mn}\right.$ (7-MeSalen $)$ $\left.\left.\left.\left(\mathrm{H}_{2} \mathrm{O}\right)\right)_{2}\left(\mathrm{Nb}_{6} \mathrm{Cl}_{12}(\mathrm{CN})_{6}\right)\right]\right\} \cdot 1.5 \mathrm{MeCN} \cdot 8 \mathrm{H}_{2} \mathrm{O}$ (2) using the ditopic ligand $\left(4,4^{\prime}-b p e\right)$ as bridging ligand, and $1 \mathrm{D}$ coordination polymer $\left[\left(4,4^{\prime}-b p e\right)\left(\mathrm{Mn}(\text { Salen })\left(\mathrm{H}_{2} \mathrm{O}\right)\right)_{2}\right]$ $\left\{\left(4,4^{\prime} \text {-bpe }\right)_{2}\left[(\mathrm{Mn}(\text { Salen })(\mathrm{MeOH}))_{2}(\mathrm{Mn}(\text { Salen }))_{2}\left(\mathrm{Nb}_{6} \mathrm{Cl}_{12}\right.\right.\right.$ $\left.\left.\left.(\mathrm{CN})_{6}\right)\right]\left[(\mathrm{Mn}(\text { Salen }))_{2}\left(\mathrm{Nb}_{6} \mathrm{Cl}_{12}(\mathrm{CN})_{6}\right)\right]\right\} \cdot 16 \mathrm{H}_{2} \mathrm{O}$ (3) in which the chains are built of alternating heterotrimers and heteropentamers connected via $4,4^{\prime}$-bpe that has been synthesized and characterized.

\section{Experimental Section}

2.1. General. Note that $\left(\mathrm{Me}_{4} \mathrm{~N}\right)_{4}\left[\mathrm{Nb}_{6} \mathrm{Cl}_{12}(\mathrm{CN})_{6}\right] \cdot 2 \mathrm{MeOH}$ [65], $[\mathrm{Mn}($ Salen $)] \mathrm{ClO}_{4} \cdot 2 \mathrm{H}_{2} \mathrm{O}$ [77], and $\left[\mathrm{Mn}_{2}(7-\right.$ MeSalen $)_{2}(\mathrm{OAc}) \mathrm{ClO}_{4}[78]$ were synthesized according to literature methods. Also, $\mathrm{LiCl}(99 \%), \mathrm{NbCl}_{5}$ (99\%, metal basis), Nb powder (99.8\%, metal basis), KCN (96\%), $\mathrm{Me}_{4} \mathrm{NCl}$ (98\%), and $o$-hydroxyacetophenone (98\%) were purchased from Alfa Aesar, while $\mathrm{Mn}(\mathrm{OAc})_{3} \cdot 2 \mathrm{H}_{2} \mathrm{O}(98 \%)$ and ethylenediamine (99\%) were purchased from ACROS. Trans-1, 2-bis(4-pyridyl)-ethylene (97\%) (4,4'-bpe) and $4,4^{\prime}$-dipyridyl N,N'-dioxide hydrate (98\%) (4,4'-dpyo) were purchased from Aldrich. Finally, $\mathrm{NaClO}_{4}$ and salicylic aldehyde were purchased from Fisher. All chemicals were used as received. Acetonitrile and methanol were used as received.

\subsection{Syntheses}

2.2.1. $\left[\mathrm{Mn}(\text { Salen })(\mathrm{MeOH})_{2}\right]_{2}\left\{\left(4,4^{\prime}\right.\right.$-dpyo $)[(\mathrm{Mn} \text { (Salen }))_{2}$ $\left.\left.\left(\mathrm{Nb}_{6} \mathrm{Cl}_{12}(\mathrm{CN})_{6}\right)\right]\right\} \cdot 2 \mathrm{MeOH}$ (1). $0.0627 \mathrm{~g} \quad(0.16 \mathrm{mmol})$ $\left[\mathrm{Mn}(\right.$ Salen $) \mathrm{ClO}_{4}$ and $0.1204 \mathrm{~g}(0.64 \mathrm{mmol}) 4,4^{\prime}-d$ pyo are dissolved in $20 \mathrm{~mL} \mathrm{MeOH}$ to get red-brown solution (A). To $4.0 \mathrm{~mL}$ of solution $\mathrm{A}$ was added $4.0 \mathrm{~mL}$ of $4.0 \mathrm{mM}$ aqueous solution of $\left(\mathrm{Me}_{4} \mathrm{~N}\right)_{4}\left[\mathrm{Nb}_{6} \mathrm{Cl}_{12}(\mathrm{CN})_{6}\right]$ (B). Dark brown plate-like crystals formed after 4 hours. The crystals were isolated by filtration, washed with two $5 \mathrm{~mL}$ portions of water and two $5 \mathrm{~mL}$ portions of $\mathrm{MeOH}$, and then dried in air (Yield: $17.4 \mathrm{mg}, 77.68 \%$; Analytical Calculation for $\mathrm{C}_{86} \mathrm{H}_{88} \mathrm{Cl}_{12} \mathrm{Mn}_{4} \mathrm{~N}_{16} \mathrm{Nb}_{6} \mathrm{O}_{16}$ : C, 36.83; H, 3.16; N, 7.99\%; Found: C, 36.26; H, 3.11; N, 8.01\%. $\nu_{\mathrm{CN}}=2137 ; 2117 \mathrm{~cm}^{-1}$ ).

2.2.2. $\left.\left[\left(4,4^{\prime} \text {-bpe }\right)(\mathrm{Mn} \text { (Salen })\left(\mathrm{H}_{2} \mathrm{O}\right)\right)_{2}\right]\left\{\left(4,4^{\prime}-\text {-bpe }\right)_{2}[(\mathrm{Mn}\right.$ (Salen) $\left.(\mathrm{MeOH}))_{2}(\mathrm{Mn}(\text { Salen }))_{2}\left(\mathrm{Nb}_{6} \mathrm{Cl}_{12}(\mathrm{CN})_{6}\right)\right][(\mathrm{Mn}$ $($ Salen $\left.\left.))_{2}\left(\mathrm{Nb}_{6} \mathrm{Cl}_{12}(\mathrm{CN})_{6}\right)\right]\right\} \cdot 16 \mathrm{H}_{2} \mathrm{O} \quad$ (3). $0.0627 \mathrm{~g} \quad(0.16$ $\mathrm{mmol})[\mathrm{Mn}($ Salen $)] \mathrm{ClO}_{4}$ and $0.1166 \mathrm{~g}$ (0.64 mmol) 4,4'-bpe are dissolved in $20 \mathrm{~mL} \mathrm{MeOH}$ to get red-brown solution (C). To $4.0 \mathrm{~mL}$ of solution $\mathrm{C}$ was added $4.0 \mathrm{~mL}$ of solution (B). Dark brown plate-like crystals formed after several hours. The crystals were filtered, washed with water and $\mathrm{MeOH}$, then dried in air (Yield: $18.0 \mathrm{mg}, 77.9 \%$; Analytical Calculation for $\mathrm{C}_{178} \mathrm{H}_{186} \mathrm{Cl}_{24} \mathrm{Mn}_{8} \mathrm{~N}_{34} \mathrm{Nb}_{12} \mathrm{O}_{36}$ : C, 36.97; $\mathrm{H}$, $3.24 ; \mathrm{N}, 8.24 \%$, found: C, 36.12; H, 2.99; N, 8.41\%. $\nu_{\mathrm{CN}}=$ $\left.2125 \mathrm{~cm}^{-1}\right)$.

2.3. Single Crystal X-Ray Structure Determinations. Intensity data for all compounds were measured at 193(2) K on a Bruker SMART APEX CCD area detector system. Data were corrected for absorption effects using the multiscan technique (SADABS). All structures were solved and refined using the Bruker SHELXTL (Version 6.1) software package. A summary of the most important crystal and structure refinement data for all compounds is given in Table 2 .

For 1, the integration of the data using a triclinic cell yielded a total of 44244 reflections to a maximum $\theta$ angle of $27.50^{\circ}$, of which 11634 were independent $\left(R_{\text {int }}=5.21 \%\right)$, and $9654(82.98 \%)$ were greater than $2 \sigma\left(\mathrm{F}^{2}\right)$. The structure was solved and refined in the space group $P 2_{1} / n$ (No. 14 ), with $Z=2$. All nonhydrogen atoms were refined anistropically. Hydrogen atoms on $\mathrm{C}$ atoms were generated and refined isotropically. The hydroxylic hydrogen atoms from the coordinated methanol molecules were located from electron density map while the one from the free methanol molecule could not be located. The final anisotropic fullmatrix least-squares refinement on $\mathrm{F}^{2}$ with 637 variables converged to $R_{1}=5.77 \%$ for observed data and $w R_{2}=$ $10.92 \%$ for all data. The largest residual peak on the final difference electron density map was $0.887 \mathrm{e}^{-} / \AA^{3}(0.89 \AA$ from $\mathrm{Nb} 2)$ and the largest hole was $-0.690 \mathrm{e}^{-} / \AA^{3}$ (1.26 $\AA$ from $\mathrm{Nb} 1)$.

For 3, the integration of the data using a triclinic cell yielded a total of 27232 reflections to a maximum $\theta$ angle of $22.0^{\circ}$, of which 12018 were independent $\left(R_{\text {int }}=2.80 \%\right)$, and $10350(86.12 \%)$ were greater than $2 \sigma\left(\mathrm{F}^{2}\right)$. The structure was solved and refined in the space group P-1 (number 2), 
TABLE 1: The six supramolecular assemblies in which the cluster $\left[\mathrm{Nb}_{6} \mathrm{Cl}_{12}(\mathrm{CN})_{6}\right]$ is linked to one, two, three, four, and six [Mn(III) $\left.(A C E N)\right]$. $\left[\mathrm{Nb}_{6}\right]$ refers to the cluster $\left[\mathrm{Nb}_{6} \mathrm{Cl}_{12}(\mathrm{CN})_{6}\right]^{4-}$ and $\left[\mathrm{Ta}_{6}\right]$ refers to the cluster $\left[\mathrm{Ta}_{6} \mathrm{Cl}_{12}(\mathrm{CN})_{6}\right]^{3-} ; \mathrm{Mn}=[\mathrm{Mn}(\mathrm{III})(A C E N)]^{+}$. $(A C E N=$ bis(acetylacetonato)ethylenediamine).

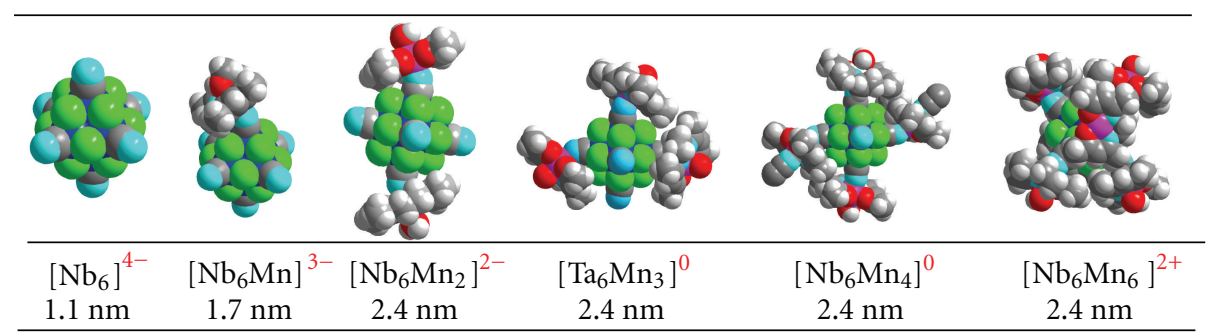

TABLE 2: Crystal data and structure refinement for the complexes.

\begin{tabular}{|c|c|c|c|}
\hline & 1 & 2 & 3 \\
\hline Formula & $\mathrm{C}_{86} \mathrm{H}_{88} \mathrm{Cl}_{12} \mathrm{Mn}_{4} \mathrm{~N}_{16} \mathrm{Nb}_{6} \mathrm{O}_{16}$ & $\mathrm{C}_{93} \mathrm{H}_{106.50} \mathrm{Cl}_{12} \mathrm{Mn}_{4} \mathrm{~N}_{17.50} \mathrm{Nb}_{6} \mathrm{O}_{18}$ & $\mathrm{C}_{178} \mathrm{H}_{186} \mathrm{Cl}_{24} \mathrm{Mn}_{8} \mathrm{~N}_{34} \mathrm{Nb}_{12} \mathrm{O}_{36}$ \\
\hline Mr. & 2804.34 & 2960.08 & 5782.89 \\
\hline Cryst. System & Monoclinic & Triclinic & Triclinic \\
\hline space group & $\mathrm{P} 2(1) / \mathrm{n}$ & P-1 & P-1 \\
\hline $\mathrm{a} / \AA$ & $16.1629(10)$ & $13.1923(16)$ & $16.9662(17)$ \\
\hline $\mathrm{b} / \AA$ & $21.2740(13)$ & $14.2188(17)$ & $17.6917(18)$ \\
\hline$c / \AA$ & $16.4062(10)$ & $16.3598(19)$ & $18.0631(18)$ \\
\hline$\alpha /$ deg & 90 & $97.737(2)$ & $74.184(2)$ \\
\hline$\beta / \operatorname{deg}$ & $115.7020(10)$ & $100.990(2)$ & $74.198(2)$ \\
\hline$\gamma / \operatorname{deg}$ & 90 & $102.532(2)$ & $75.567(2)$ \\
\hline $\mathrm{V}\left(\AA^{3}\right) / \mathrm{Z}$ & $5083.1(5) / 2$ & $2890.7(6) / 1$ & $4928.9(9) / 1$ \\
\hline $\mathrm{d}_{\text {calcd }}, \mathrm{g} / \mathrm{cm}^{3}$ & 1.832 & 1.700 & 2.745 \\
\hline $\mathrm{F}(000)$ & 2788 & 1481 & 3780 \\
\hline$\theta$ range $\left({ }^{\circ}\right)$ & $3.80 \sim 27.50$ & $3.83 \sim 27.50$ & $3.76 \sim 22.00$ \\
\hline Reflections collected/unique & $44244 / 11634$ & $25667 / 13079$ & $27232 / 12018$ \\
\hline$R($ int $)$ & 0.0521 & 0.0327 & 0.0280 \\
\hline Goodness-of-fit on $\mathrm{F}^{2}$ & 1.159 & 1.028 & 1.048 \\
\hline \multicolumn{4}{|l|}{$R_{1},{ }^{*} w R_{2} * *$} \\
\hline $\mathrm{I}>2 \sigma(\mathrm{I})$ & $R_{1}=0.0577, w R_{2}=0.1046$ & $R_{1}=0.0435, w R_{2}=0.1049$ & $R_{1}=0.0974, w R_{2}=0.2674$ \\
\hline all data & $R_{1}=0.0743, w R_{2}=0.1092$ & $R_{1}=0.0581, w R_{2}=0.1130$ & $R_{1}=0.1081, w R_{2}=0.2764$ \\
\hline Max/mean shift in final cycle & $0.001 / 0.000$ & $0.001 / 0.000$ & $0.309 / 0.023$ \\
\hline
\end{tabular}

${ }^{*} R_{1}=\sum\left(\left\|F_{o}|-| F_{c}\right\|\right) / \sum\left|F_{o}\right|, * * w R_{2}=\left\{\sum w\left[\left(F_{o}^{2}-F_{c}^{2}\right)\right] / \sum w\left[\left(F_{o}^{2}\right)^{2}\right]\right\}^{0.5}, w=\left[\sigma^{2}\left(F_{o}^{2}\right)+(a P)^{2}+b P\right]^{-1}$, where $\left.P=\left(F_{o}^{2}+2 F_{c}^{2}\right) / 3\right] .1, a=0.0322, b=$ $15.5540 ; 2, a=0.0598, b=0.8822 ; 3, a=0.1589, b=80.8760$.

with $Z=1$. All nonhydrogen atoms in the framework were located from Fourier difference map while the free solvent molecules and hydrogen atoms could not be located. No attempt was made to locate hydrogen atoms on $\mathrm{C}$ atoms. The final anisotropic full-matrix least-square refinement on $\mathrm{F}^{2}$ with 1217 variables converged to $R_{1}=9.74 \%$ for observed data and $w R_{2}=27.64 \%$ for all data.

2.4. Other Physical Measurements. Elemental analyses were carried out by Atlantic Microlab, Inc. Thermogravimetric analyses were performed on $\sim 14 \mathrm{mg}$ samples under a flow of argon or air $(40 \mathrm{~mL} / \mathrm{min})$ at a ramp rate of $5^{\circ} \mathrm{C} / \mathrm{min}$, using a Perkin-Elmer Pyris 1 TGA system. Infrared spectra were recorded as $\mathrm{KBr}$ pellets on a Mattson Infinity System FTIR spectrometer. The magnetic susceptibility data were collected using a Quantum Design MPMS SQUID mag- netometer. Approximately, $15 \mathrm{mg}$ samples were packed in gelatin capsules between cotton plugs. The data obtained have been corrected for the diamagnetic contribution of the sample holder, the diamagnetism of the closed shell octahedral $\left\{\mathrm{Nb}_{6}\right\}$ cluster [79] and diamagnetic contribution of all other atoms using Pascal's constants [80].

$\mathrm{X}$-ray powder diffraction data was collected at room temperature using a BRUKER P4 general-purpose fourcircle X-ray diffractometer equipped with a GADDS/Hi-Star detector positioned $20 \mathrm{~cm}$ from the sample. The goniometer was controlled using the GADDS software suite [81]. The sample was mounted on tape and data was recorded in transmission mode. The data was reduced by area integration methods to produce a single powder diffraction pattern for each frame. Individual powder diffraction patterns were merged and analyzed with the program EVA [82]. 


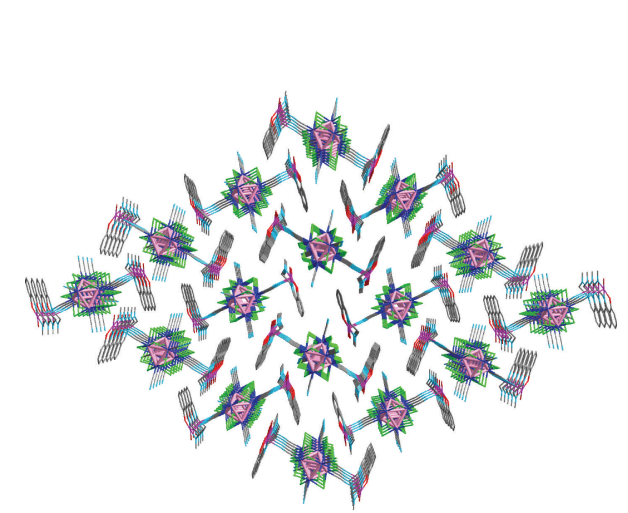

(a)

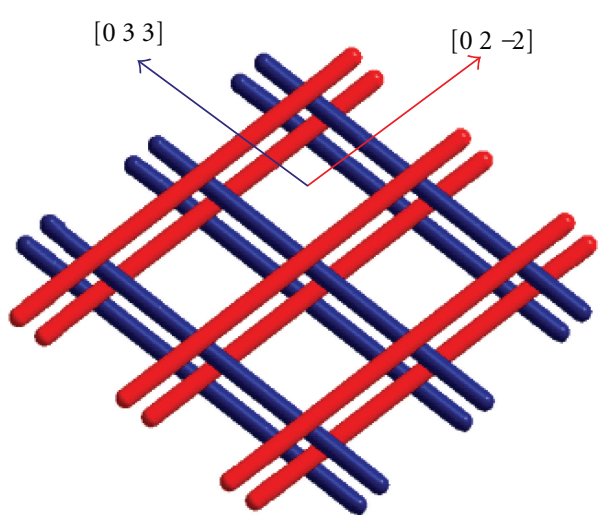

(b)

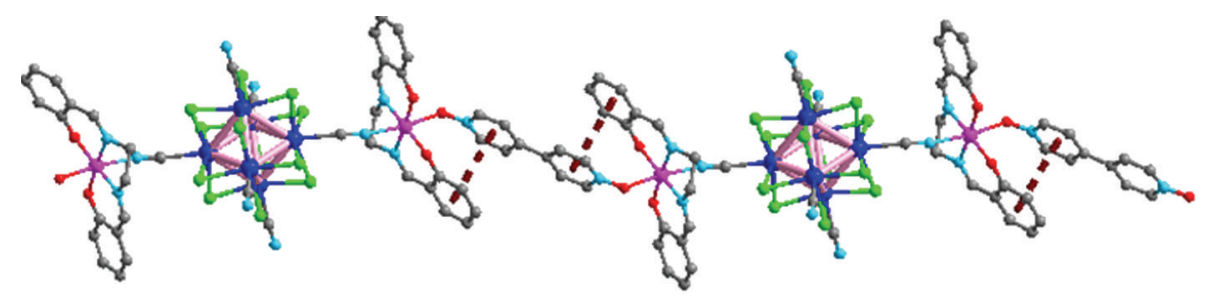

(c)

Figure 1: (a) A perspective view of the structure of 1 . Note that $\left[\mathrm{Mn}(\mathrm{Salen})(\mathrm{MeOH})_{2}\right]^{+}$cations are represented as space-filling mode and some cations are omitted to show the size and shape of the channel. (b) Schematic diagram showing the packing mode of the chains along [ $\left[\begin{array}{lll}0 & 2 & -2\end{array}\right]$ and $\left[\begin{array}{lll}0 & 3 & 3\end{array}\right]$ directions. (c) A projection of one anionic chain showing the linkages between the three components and $\pi-\pi$ interaction between $d p y o$ and the Salen ligand represented as dotted brown line.

\section{Results and Discussion}

3.1. Structure of Compound 1. Compound $\mathbf{1}$ features $1 \mathrm{D}$ anionic chains with $\left[\mathrm{Mn}(\text { Salen })(\mathrm{MeOH})_{2}\right]^{+}$as charge compensating ions (Figure 1). The chains are built of heterotrimer $\left[(\mathrm{Mn}(\text { Salen }))_{2}\left(\mathrm{Nb}_{6} \mathrm{Cl}_{12}(\mathrm{CN})_{6}\right)\right]^{2-}$ building blocks which are connected to each other by $4,4^{\prime}-d p y o$ ditopic linkers. Within the heterotrimer, the cluster $\left[\mathrm{Nb}_{6} \mathrm{Cl}_{12}(\mathrm{CN})_{6}\right]^{4-}$ is characterized by its octahedral $\left\{\mathrm{Nb}_{6}\right\}$ metal core equipped with 12 edge-bridging $\mathrm{Cl}$ ligands and 6 terminal $\mathrm{CN}^{-}$ ligands, with bond lengths ( $\mathrm{Nb}-\mathrm{Nb}=2.934(8) \AA)$ and angles typical for niobium hexacyanochloride clusters with 16 valence electrons per cluster [34-43]. Each cluster uses the nitrogen ends of two cyanide ligands located opposite to each other to connect to two Mn complexes in transmode with $\mathrm{Nb}-\mathrm{C}=2.271(5) \AA$ and $\mathrm{C} \equiv \mathrm{N}=1.140(6) \AA$. Two of the four non-bridging cyanide ligands engage in extensive hydrogen bonding with the methanol ligand of the $\left[\mathrm{Mn}(\text { Salen })(\mathrm{MeOH})_{2}\right]^{+}$cations with $\mathrm{O} \cdots \mathrm{N}$ separation of $2.771(6) \AA$ and $\mathrm{O}-\mathrm{H} \cdots \mathrm{N}$ angle of $170(8)^{\circ}$. The remaining two cyanide ligands are linked to niobium only, with bond lengths $\mathrm{Nb}-\mathrm{C}=2.271(5) \AA$ and $\mathrm{C} \equiv \mathrm{N}=1.151(6) \AA$. Although there are three kinds of cyanide groups in the structure, only two absorption bands related to the $\mathrm{CN}$ stretching vibrational mode $\left(2137,2117 \mathrm{~cm}^{-1}\right)$ are observed in the IR spectrum. The $2137 \mathrm{~cm}^{-1}$ band is assigned to the $\mathrm{CN}$ which is attached to the cluster only, and the $2117 \mathrm{~cm}^{-1}$ band is assigned to the $\mathrm{CN}$ ligand that acts either as a linker to Mn or is involved in hydrogen bonding with the methanol ligand.
The $\mathrm{Mn}^{3+}$ ions within the chains have a distorted octahedral coordination environment with two $\mathrm{N}$ and two $\mathrm{O}$ from the Salen ligand (average $\mathrm{Mn}-\mathrm{O}=1.88(2) \AA$ and $\mathrm{Mn}-\mathrm{N}$ $=1.986(2) \AA$, compared to $1.88(3) \AA$ and 1.983(2) $\AA$ found in $\left[\mathrm{Mn}(\right.$ Salen $\left.) \mathrm{Cl}\left(\mathrm{H}_{2} \mathrm{O}\right)\right]$ [83]. The two axial sites are occupied by one $\mathrm{N}$ from a cyanide ligand from the cluster with $\mathrm{Mn}-\mathrm{N}_{\mathrm{CN}}=2.263(4) \AA$ and $\angle \mathrm{C} \equiv \mathrm{N}-\mathrm{Mn}=153.6(4)^{\circ}$, and one O from the $4,4^{\prime}-d$ pyo with $\mathrm{Mn}-\mathrm{O}_{d p y o}=2.217(4) \AA, \angle \mathrm{N}_{d p y o}-$ $\mathrm{O}_{d p y o}-\mathrm{Mn}=119.2(3)^{\circ}$. The cluster unit and the $4,4^{\prime}-d p y o$ linker are located on the same side of the $\mathrm{N}_{\mathrm{CN}}-\mathrm{Mn}-\mathrm{O}_{d p \text { yo }}$ axis leading to zig-zag wave-like chains. To the best of our knowledge, this is the first example where the $[\mathrm{Mn}(\text { Salen })]^{+}$ complex uses its two open axial sites to coordinate to two different bridging ligands to form an extended structure.

The $4,4^{\prime}$-dpyo ligand connects the heterotrimers into a $1 \mathrm{D}$ coordination polymer via a coordination bond between its oxygen ends and $[\mathrm{Mn}(\text { Salen })]^{+}$complexes. Intrachain offset face-to-face $\pi-\pi$ interactions between the Salen ligand and $4,4^{\prime}$-dpyo with ring. . ring distance of $3.70 \AA$ are observed. The chains run along [ [ $\left.\begin{array}{lll}0 & 3 & 3\end{array}\right]$ and $\left[\begin{array}{llll}0 & 2 & - & 2\end{array}\right]$ crystallographic directions and are packed into alternating layers. The packing leads to the formation of channels along the $a$ direction where the cations and free solvent molecules are located.

The charge of the anionic chain is compensated by two $\left[\mathrm{Mn}(\text { Salen })(\mathrm{MeOH})_{2}\right]^{+}$cations in which $\mathrm{Mn}^{3+}$ is chelated by a Salen ligand and coordinated by two methanol ligands with $\mathrm{Mn}-\mathrm{O}=2.270(4)$ and 2.233(5) $\AA$. One of the methanol ligands forms a hydrogen bond with nonbridging cyanide 


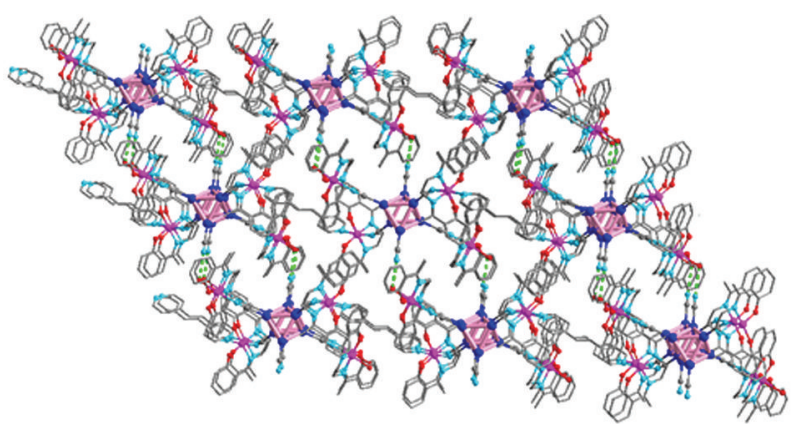

(a)

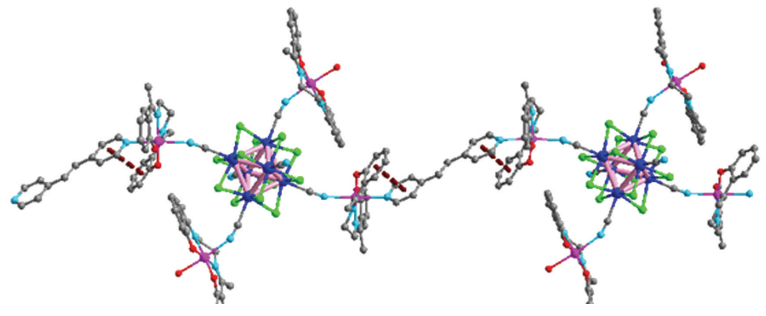

(b)

Figure 2: The structure of 2. (a) The packing diagram viewed along the $a$ direction. $\mathrm{Cl}$ atoms and free solvent molecules are omitted for clarity. Hydrogen bond is represented as a dotted green line. (b) The 1D neutral chain, $\pi-\pi$ interaction is represented as a dotted red line.

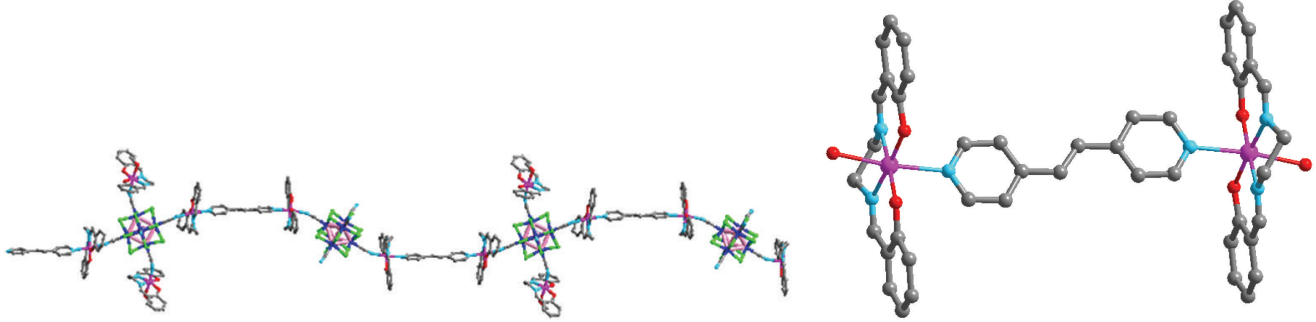

(a)

(b)

Figure 3: The structure of 3 (a) $1 \mathrm{D}$ anionic chain. (b) The cation: $\left\{\left[\mathrm{Mn}(\text { Salen })\left(\mathrm{H}_{2} \mathrm{O}\right)\right]_{2}\left(4,4^{\prime}-b p e\right)\right\}^{2+}$.

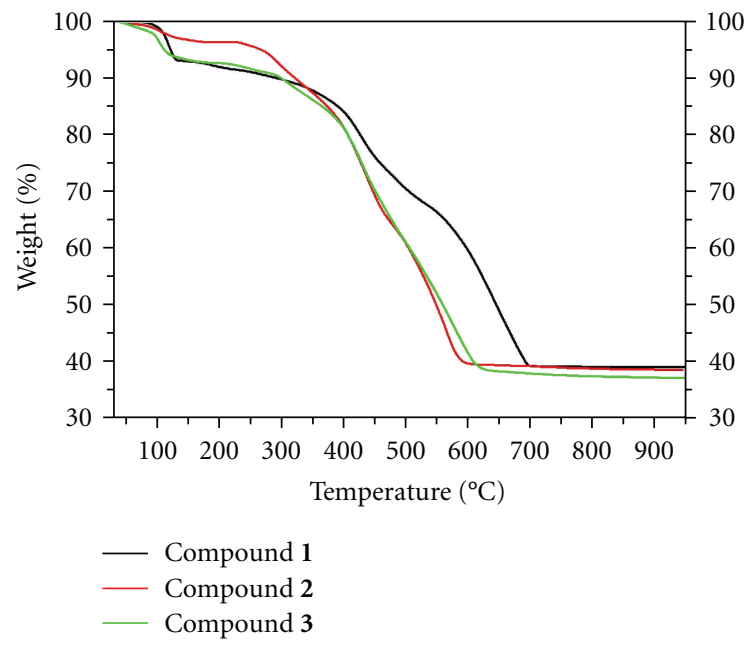

Figure 4: TGA plots for compounds $1-3$ from $30^{\circ} \mathrm{C}$ to $950^{\circ} \mathrm{C}$ at $5^{\circ} \mathrm{C} / \mathrm{min}$ under air flow $(40 \mathrm{~mL} / \mathrm{min})$.

ligand and the other forms a strong hydrogen bond with the free methanol molecule with $\mathrm{O} \cdots \mathrm{O}$ separation of 2.558(9) $\AA$ and $\mathrm{O}-\mathrm{H} \cdots \mathrm{O}$ angle of $175(9)^{\circ}$. In addition to hydrogen bonds, the cation is also involved in an edge to face

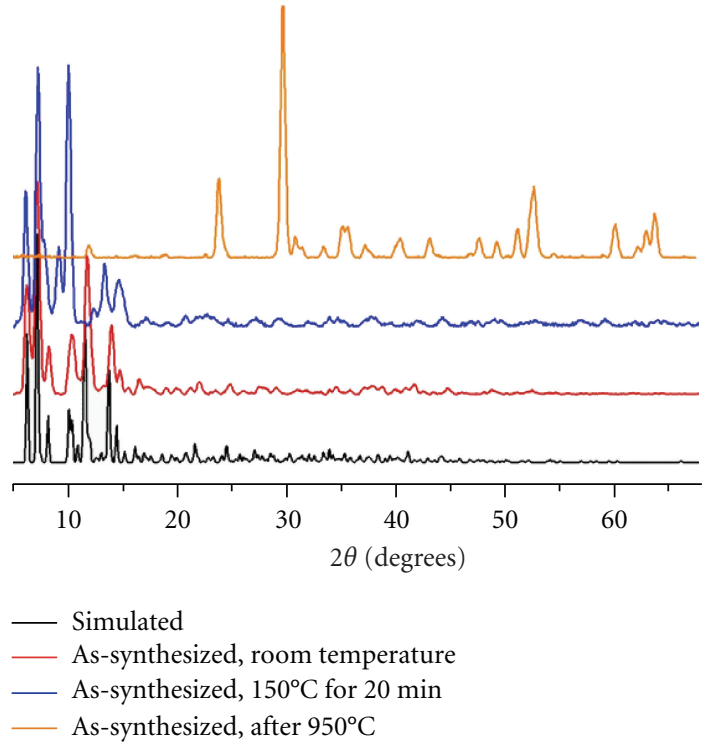

Figure 5: Powder X-ray diffraction patterns of 1: pattern simulated from crystal structure in black; observed pattern at room temperature in red; observed pattern after being heated at $150^{\circ} \mathrm{C}$ for 20 minutes in blue; observed pattern after being heated to $950^{\circ} \mathrm{C}$ in orange which corresponds to a mixture of $\mathrm{MnNb}_{2} \mathrm{O}_{6}$ and $\mathrm{Mn}_{3} \mathrm{O}_{4}$. 


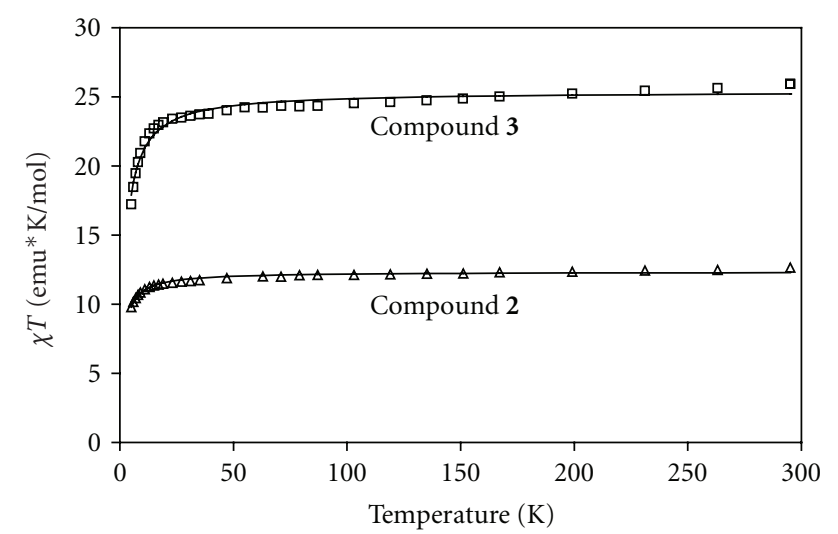

FIgURE 6: Temperature dependence of magnetic susceptibilies for compounds 2 and 3 (5-300 K at $1000 \mathrm{G})$.

$\pi-\pi$ interaction with the anionic chain $\left(\mathrm{H}_{5 \mathrm{~A}}-\mathrm{Ring}_{\mathrm{C} 17-\mathrm{C} 22}=\right.$ $2.68 \AA$ and $\mathrm{H}_{2 \mathrm{~A}}-$ Ring $_{\mathrm{C} 27-\mathrm{C} 32}=2.60 \AA$ ).

3.2. Structure of Compound 2. Compound 2 was reported earlier by us and is given here for comparison purpose only [68]. The neutral chains in 2 are built of neutral heteropentamers $\left[(\mathrm{Mn}(7-\mathrm{MeSalen}))_{4}\left(\mathrm{Nb}_{6} \mathrm{Cl}_{12}(\mathrm{CN})_{6}\right)\right]$ linked by 4,4'-bpe ligands (Figure 2). In each heteropentamer, the $\left[\mathrm{Nb}_{6} \mathrm{Cl}_{12}(\mathrm{CN})_{6}\right]^{4-}$ cluster uses four of its six cyanide ligands to connect to four Mn complexes through cyanide bridges and the octahedral coordination environment of each $\mathrm{Mn}(\mathrm{III})$ ion is completed by one $\mathrm{N}$ from a $4,4^{\prime}$-bpe ligand, which links the heteropentamers into chains running along the $\left[\begin{array}{lll}-1 & 1 & 1\end{array}\right]$ direction. An intrachain offset face-to-face $\pi-\pi$ interaction between the 7 MeSalen ligand and 4,4'-bpe with ring $\cdots$ ring distance of $3.72 \AA$ leads to the bending of the 7-MeSalen ligand: the dihedral angle between the two benzene rings of the ligand is $42.3^{\circ}$, compared with $19.6^{\circ}$ in 1 . The location of the cyanide and the bpe ligands on the same side of the $\mathrm{N}_{\mathrm{CN}}-\mathrm{Mn}-\mathrm{N}_{\text {bpe }}$ axis leads to chains with a sinusoidal wave-like structure. Hydrogen bonds between nonbridging cyanides and the aqua ligands further connect the chains into layers (Figure 2(a)) which are held together through hydrogen bonding between disordered water molecules.

3.3. Structure of Compound 3. The reaction of $\mathrm{Mn}($ Salen $) \mathrm{Cl}$, $\left(\mathrm{Nb}_{6} \mathrm{Cl}_{12}(\mathrm{CN})_{6}\right)^{4-}$ and 4,4'-bpe in $\mathrm{MeOH}-\mathrm{H}_{2} \mathrm{O}$ solvent leads to compound 3 , which crystallizes in the triclinic system, space group P-1 with $a=16.9662(17)$, $b=17.6917(18), c=18.0631(18) \AA, \alpha=74.184(2)$, $\beta=74.198(2), \gamma=75.567(2)^{\circ}, V=4928.9(9) \AA^{3}$, and $Z=1$. Data collected on three different crystals indicated complex twinning problems that could not be modeled. However, the data was sufficiently good to give the overall framework. The compound consists of 1D anionic chains built of two different nodes: anionic heterotrimers $\left[(\mathrm{Mn}(\text { Salen }))_{2}\left(\mathrm{Nb}_{6} \mathrm{Cl}_{12}(\mathrm{CN})_{6}\right)\right]^{2-}$ and neutral heteropentamers $\left[(\mathrm{Mn}(\text { Salen }))_{4}\left(\mathrm{Nb}_{6} \mathrm{Cl}_{12}(\mathrm{CN})_{6}\right)\right]$ linked to one another by $4,4^{\prime}$-bpe ligands (Figure 3 ). In the heteropentamer, the sixth coordination site of the nonbridged $(\mathrm{Mn}(\mathrm{Salen}))^{+}$complexes are occupied by methanol molecules. No intrachain $\pi-\pi$ interactions between the Salen ligand and the aromatic part of the bridging ligand are observed compared to the relatively strong interactions present in 1 and 2. The in situ formed dimeric cation $\left\{\left[\mathrm{Mn}(\text { Salen })\left(\mathrm{H}_{2} \mathrm{O}\right)\right]_{2}\left(4,4^{\prime}-\text {-bpe }\right)\right\}^{2+}$ is used to balance the chains' negative charge. No free solvent molecules could be located from the electron density map and the presence of 16 waters of crystallization was determined based on elemental analysis and TGA data.

The connectivity mode $\left\{\mathrm{Nb}_{6}\right\}-\mathrm{C} \equiv \mathrm{N}-\mathrm{Mn}-\mathrm{L}_{\text {bridge }}-\mathrm{Mn}-$ $\mathrm{N} \equiv \mathrm{C}-\left\{\mathrm{Nb}_{6}\right\}$ observed in the three compounds is different from that observed in a series of $\left\{\operatorname{Re}_{6}\right\}$ based compounds in which $\left(\left\{\operatorname{Re}_{6}\right\}-\mathrm{L}_{\text {bridge }}-\mathrm{M}-\mathrm{L}_{\text {bridge }}-\left\{\mathrm{Re}_{6}\right\}\right)$ is observed [8487]. Simultaneous use of $\mathrm{CN}$ and ditopic ligands as bridges has been observed in mononuclear cyanometallate-based coordination polymers [88-93], however similar structures have never been reported for cluster-based coordination networks.

3.4. Thermal Stabilities. Polycrystalline samples of each compound were used to study the thermal stability of the three compounds (Figure 4). TGA of 1 shows two distinct weight losses. The first $(6.84 \%)$ corresponds to loss of all coordinated and free solvent molecules at temperature below $200^{\circ} \mathrm{C}$ (cal. 6.85\%). The powder Xray diffraction pattern of samples obtained after heating (1) at $150^{\circ} \mathrm{C}$ for 20 minutes is virtually the same as that of 1 except for the peak at $2 \theta=8.300^{\circ}$ which shifts to $2 \theta=9.087^{\circ}$ indicating minor structural transformations. IR spectra of the materials obtained after being heated at $150^{\circ} \mathrm{C}$ for 20 minutes was found to be the same as those of the original compound indicating the conservation of all functional components. The compound continues to loose weight after $200^{\circ} \mathrm{C}$ without any well-defined phase being formed indicating a continuous decomposition until $700^{\circ} \mathrm{C}$ is reached. The final product obtained after $700^{\circ} \mathrm{C}$ is a mixture of the oxides $\mathrm{MnNb}_{2} \mathrm{O}_{6}$ and $\mathrm{Mn}_{3} \mathrm{O}_{4}$, as confirmed by PXRD (Figure 5) $(\%$ loss $($ obs. $)=61.02 \%$; \%loss $($ calc. $)=61.26 \%)[94,95]$. The overall chemical equation for this process can be written as

$\left[\mathrm{Mn}(\text { Salen })(\mathrm{MeOH})_{2}\right]_{2}\left\{\left(4,4^{\prime}-\right.\right.$ dpyo $\left.)\left[(\mathrm{Mn}(\text { Salen }))_{2}\left(\mathrm{Nb}_{6} \mathrm{Cl}_{12}(\mathrm{CN})_{6}\right)\right]\right\} \cdot 2 \mathrm{MeOH}$

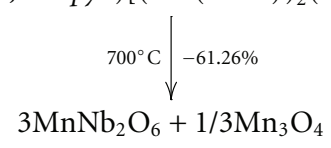


Compound 2 has similar thermal behavior as that observed for 1. It first loses solvent molecules (1.5 MeCN and $3 \mathrm{H}_{2} \mathrm{O}$ before $180^{\circ} \mathrm{C}$ (\%loss (obs.) $=3.69 \%$, loss (calc.) $=3.90 \%)$ ) and forms a desolvated phase which is stable up to $300^{\circ} \mathrm{C}$ as confirmed by PXRD and IR (SI). The compound decomposes to form a mixture of $\mathrm{MnNb}_{2} \mathrm{O}_{6}$ and $\mathrm{Mn}_{3} \mathrm{O}_{4}$ at temperatures above $580^{\circ} \mathrm{C}$ (\%loss (obs.) $=61.59 \%$, \%loss $($ calc. $)=62.41 \%)$.

Compound 3 loses all its solvent molecules (2 coordinated $\mathrm{MeOH}, 2$ coordinated $\mathrm{H}_{2} \mathrm{O}$, and 16 lattice water molecules $(\%$ loss $($ obs. $)=7.02 \%$, loss $($ calc. $)=6.71 \%)$ ) before $150^{\circ} \mathrm{C}$. The dessolvated phase loses crystallinity as indicated by a decrease in diffraction peaks intensity. IR spectra (SI), however, indicate the presence of $\mathrm{CN}$ as well as salen and bridging ligand. The compound continues to decompose after $300^{\circ} \mathrm{C}$ without any stable phases until it reaches $625^{\circ} \mathrm{C}$ when it forms a mixture of $\mathrm{MnNb}_{2} \mathrm{O}_{6}$ and $\mathrm{Mn}_{3} \mathrm{O}_{4}$ (\%loss (obs.) $=63.00 \%$, \%loss (calc.) $=62.42 \%$ ) as confirmed by PXRD (SI). The overall decomposition reaction can be written as follows:

$\left[\left(4,4^{\prime}-\right.\right.$-bpe $\left.)\left(\mathrm{Mn}(\text { Salen })\left(\mathrm{H}_{2} \mathrm{O}\right)\right)_{2}\right]\left\{\left(4,4^{\prime}-\text { bpe }\right)_{2}\left[(\mathrm{Mn}(\text { Salen })(\mathrm{MeOH}))_{2}(\mathrm{Mn}(\text { Salen }))_{2}\left(\mathrm{Nb}_{6} \mathrm{Cl}_{12}(\mathrm{CN})_{6}\right)\right]\left[(\mathrm{Mn}(\mathrm{Salen}))_{2}\left(\mathrm{Nb}_{6} \mathrm{Cl}_{12}(\mathrm{CN})_{6}\right)\right]\right\} \cdot 16 \mathrm{H}_{2} \mathrm{O}(\mathbf{3})$
$625^{\circ} \mathrm{C} \downarrow-62.42 \%$
$\downarrow$
$2\left(3 \mathrm{MnNb}_{2} \mathrm{O}_{6}+1 / 3 \mathrm{Mn}_{3} \mathrm{O}_{4}\right)$

3.5. Magnetic Properties. Magnetic properties of $\mathbf{2}$ and $\mathbf{3}$ were measured upon warming from 5 to $300 \mathrm{~K}$ in an applied field of $1000 \mathrm{G}$ (Figure 6). Because previous reports have shown that the niobium cluster is diamagnetic with a temperature independent paramagnetism term $[96,97]$, it is reasonable to model the temperature-dependent paramagnetism as due solely to the $\mathrm{Mn}$ (III) centers. The data can be fit to a CurieWeiss expression for each of the compounds to yield $g_{\text {ave }}=$ $2.03, \theta=-1.3 \mathrm{~K}$, and $g_{\text {ave }}=2.06, \theta=-2.1 \mathrm{~K}$, respectively. These values are consistent with four and eight high-spin $\mathrm{Mn}$ (III) centers for compounds $\mathbf{2}$ and $\mathbf{3}$. The slight downturn in the data at low temperatures is probably due to zero field splitting of the $S=2$ ground state. The values obtained are comparable to those reported for 1D coordination polymer built of well-separated $[\mathrm{Mn}(\text { Salen })]^{+}$centers $[98,99]$.

\section{Conclusion}

In summary, trimeric $(\mathrm{T})$ and pentameric $(\mathrm{P})$ nanoscopic supramolecular species $(\sim 2 \mathrm{~nm})$ based on the diamagnetic 16 electron cyanochloride cluster $\left[\mathrm{Nb}_{6} \mathrm{Cl}_{12}(\mathrm{CN})_{6}\right]^{4-}$ coordinated by 2 or $4 \mathrm{Mn}$ (III) complexes have been assembled into extended frameworks via bridging ditopic organic ligands $(\mathrm{O})$ through self-assembly processes. The bridging modes can be described as (-T-O-T-O-) in 1, (-P-O$\mathrm{P}-\mathrm{O}-)$ in 2 , and (-T-O-P-O-T-) in 3. The compounds are chemically and thermally stable and their magnetic properties are consistent with the long distances between the manganese(III) centers. The assembly of such complex materials containing large supramolecular species linked to each other via ditopic organic ligands in a simple onepot reaction indicates the tremendous opportunities this chemistry provides. We have recently developed synthesis methodologies for the synthesis of the 14 and 15 electron $\left\{\mathrm{Nb}_{6}\right\}$ and $\left\{\mathrm{Ta}_{6}\right\}$ cyano- and azido-chloride clusters and we are investigating their use as building blocks to study the effect of the metal, the ligand and the electronic structure of the cluster on the properties of these materials.

\section{Acknowledgment}

The authors wish to thank Professor Gordon T. Yee and Dr. Mark D. Harvey for magnetic data measurements. This material is based upon work supported by the National Science Foundation under Grant Nos. DMR-0446763 and 0234489.

\section{References}

[1] A. K. Cheetham, G. Férey, and T. Loiseau, "Open-framework inorganic materials," Angewandte Chemie International Edition, vol. 38, no. 22, pp. 3269-3292, 1999.

[2] A. K. Cheetham, C. N. R. Rao, and R. K. Feller, "Structural diversity and chemical trends in hybrid inorganic-organic framework materials," Chemical Communications, no. 46, pp. 4780-4795, 2006.

[3] B. Kesanli and W. Lin, "Chiral porous coordination networks: rational design and applications in enantioselective processes," Coordination Chemistry Reviews, vol. 246, no. 1-2, pp. 305326, 2003.

[4] N. L. Rosi, M. Eddaoudi, J. Kim, M. O'Keeffe, and O. M. Yaghi, "Advances in the chemistry of metal-organic frameworks," CrystEngComm, vol. 4, pp. 401-404, 2002.

[5] S. L. James, "Metal-organic frameworks," Chemical Society Reviews, vol. 32, no. 5, pp. 276-288, 2003.

[6] M. O'Keeffe, M. Eddaoudi, H. Li, T. Reineke, and O. M. Yaghi, "Frameworks for extended solids: geometrical design principles," Journal of Solid State Chemistry, vol. 152, no. 1, pp. 3-20, 2000.

[7] O. M. Yaghi, M. O’Keeffe, N. W. Ockwig, H. K. Chae, M. Eddaoudi, and J. Kim, "Reticular synthesis and the design of new materials," Nature, vol. 423, no. 6941, pp. 705-714, 2003.

[8] H. K. Chae, D. Y. Siberio-Perez, J. Kim, et al., "A route to high surface area, porosity and inclusion of large molecules in crystals," Nature, vol. 427, no. 6974, pp. 523-527, 2004.

[9] B. Moulton and M. J. Zaworotko, "From molecules to crystal engineering: supramolecular isomerism and polymorphism in network solids," Chemical Reviews, vol. 101, no. 6, pp. 1629$1658,2001$. 
[10] M. Eddaoudi, D. B. Moler, H. Li, et al., "Modular chemistry: secondary building units as a basis for the design of highly porous and robust metal-organic carboxylate frameworks," Accounts of Chemical Research, vol. 34, no. 4, pp. 319-330, 2001.

[11] J. L. C. Rowsell, J. Eckert, and O. M. Yaghi, "Characterization of $\mathrm{H}_{2}$ binding sites in prototypical metal-organic frameworks by inelastic neutron scattering," Journal of the American Chemical Society, vol. 127, no. 42, pp. 14904-14910, 2005.

[12] S. Ma, D. Sun, X.-S. Wang, and H.-C. Zhou, "A meshadjustable molecular sieve for general use in gas separation," Angewandte Chemie International Edition, vol. 46, no. 14, pp. 2458-2462, 2007.

[13] B. Kesanli, Y. Cui, M. R. Smith, E. W. Bittner, B. C. Bockrath, and W. Lin, "Highly interpenetrated metal-organic frameworks for hydrogen storage," Angewandte Chemie International Edition, vol. 44, no. 1, pp. 72-75, 2004.

[14] J. Y. Lee, L. Pan, S. P. Kelly, J. Jagiello, T. J. Emge, and J. Li, "Achieving high density of adsorbed hydrogen in microporous metal organic frameworks," Advanced Materials, vol. 17, no. 22, pp. 2703-2706, 2005.

[15] S. Kitagawa, "Physical chemistry: gas in a straitjacket," Nature, vol. 441, no. 7093, pp. 584-585, 2006.

[16] Y. Kubota, M. Takata, R. Matsuda, et al., "Direct observation of hydrogen molecules adsorbed onto a microporous coordination polymer," Angewandte Chemie International Edition, vol. 44, no. 6, pp. 920-923, 2005.

[17] C.-D. Wu, A. Hu, L. Zhang, and W. Lin, "A homochiral porous metal-organic framework for highly enantioselective heterogeneous asymmetric catalysis," Journal of the American Chemical Society, vol. 127, no. 25, pp. 8940-8941, 2005.

[18] L. Pan, D. H. Olson, L. R. Ciemnolonski, R. Heady, and J. $\mathrm{Li}$, "Separation of hydrocarbons with a microporous metalorganic framework," Angewandte Chemie International Edition, vol. 45, no. 4, pp. 616-619, 2006.

[19] X.-Y. Wang, Z.-M. Wang, and S. Gao, "A pillared layer MOF with anion-tunable magnetic properties and photochemical [2+2] cycloaddition," Chemical Communications, no. 11, pp. 1127-1129, 2007.

[20] S. Xiang, X. Wu, J. Zhang, et al., "A 3D canted antiferromagnetic porous metal-organic framework with anatase topology through assembly of an analogue of polyoxometalate," Journal of the American Chemical Society, vol. 127, no. 47, pp. 1635216353, 2005.

[21] H.-Z. Kou, B. C. Zhou, S. Gao, and R.-J. Wang, "A 2D cyano- and oxamidato-bridged heterotrimetallic CrIII-CuIIGDIII complex," Angewandte Chemie International Edition, vol. 42, no. 28, pp. 3288-3291, 2003.

[22] O. Maury and H. Le Bozec, "Molecular engineering of octupolar NLO molecules and materials based on bipyridyl metal complexes," Accounts of Chemical Research, vol. 38, no. 9, pp. 691-704, 2005.

[23] O. R. Evans and W. Lin, "Crystal engineering of NLO materials based on metal-organic coordination networks," Accounts of Chemical Research, vol. 35, no. 7, pp. 511-522, 2002.

[24] J.-J. Zhang, T.-L. Sheng, S.-M. Hu, et al., "Two 3D supramolecular polymers constructed from an amino acid and a highnuclear $\operatorname{Ln}_{6} \mathrm{Cu}_{24}$ cluster node," Chemistry, vol. 10, no. 16, pp. 3963-3969, 2004.

[25] A. Kuc, A. Enyashin, and G. Seifert, "Metal-organic frameworks: structural, energetic, electronic, and mechanical properties," Journal of Physical Chemistry B, vol. 111, no. 28, pp. 8179-8186, 2007.
[26] F. A. Cotton, C. Lin, and C. A. Murillo, "Supramolecular arrays based on dimetal building units," Accounts of Chemical Research, vol. 34, no. 10, pp. 759-771, 2001.

[27] M. Eddaoudi, D. B. Moler, H. Li, et al., "Modular chemistry: secondary building units as a basis for the design of highly porous and robust metal-organic carboxylate frameworks," Accounts of Chemical Research, vol. 34, no. 4, pp. 319-330, 2001.

[28] B.-Q. Ma, D.-S. Zhang, S. Gao, T.-Z. Jin, C.-H. Yan, and G.-X. $\mathrm{Xu}$, "From cubane to supercubane: the design, synthesis, and structure of a three-dimensional open framework based on a $\mathrm{Ln}_{4} \mathrm{O}_{4}$ cluster," Angewandte Chemie International Edition, vol. 39, no. 20, pp. 3644-3646, 2000.

[29] L. Song, J. Li, P. Lin, et al., "Synthesis and crystal structures of multidimensional coordination polymers based on W/Cu/S clusters with flexible imidazole ligands," Inorganic Chemistry, vol. 45, no. 25, pp. 10155-10161, 2006.

[30] E. J. Welch and J. R. Long, "Atomlike building units of adjustable character: solid-state and solution routes to manipulating hexanuclear transition metal chalcohalide clusters," Progress in Inorganic Chemistry, vol. 54, pp. 1-45, 2005.

[31] J.-C. P. Gabriel, K. Boubekeur, S. Uriel, and P. Batail, "Chemistry of hexanuclear rhenium chalcohalide clusters," Chemical Reviews, vol. 101, no. 7, pp. 2037-2066, 2001.

[32] H. D. Selby, B. K. Roland, and Z. Zheng, "Ligand-bridged oligomeric and supramolecular arrays of the hexanuclear rhenium selenide clusters-exploratory synthesis, structural characterization, and property investigation," Accounts of Chemical Research, vol. 36, no. 12, pp. 933-944, 2003.

[33] T. G. Gray, "Hexanuclear and higher nuclearity clusters of the Groups 4-7 metals with stabilizing $\Pi$-donor ligands," Coordination Chemistry Reviews, vol. 243, no. 1-2, pp. 213235, 2003.

[34] R. Chevrel, M. Sergent, and J. Prigent, "Sur de nouvelles phases sulfurées ternaires du molybdène," Journal of Solid State Chemistry, vol. 3, no. 4, pp. 515-519, 1971.

[35] O. Fischer and M. B. Maple, Eds., Superconductivity in Ternary Compounds, vol. 32 of Top. Curr. Phys., Springer, Berlin, Germany, 1982.

[36] C. Fischer, N. Alonso-Vante, S. Fiechter, and H. Tributsch, "Electrocatalytic properties of mixed transition metal tellurides (Chevrel-phases) for oxygen reduction," Journal of Applied Electrochemistry, vol. 25, no. 11, pp. 1004-1008, 1995.

[37] K. Suzuki, T. Iijima, and M. Wakihara, "Chromium Chevrel phase sulfide (CrxMo6S8-y) as the cathode with long cycle life in lithium rechargeable batteries," Solid State Ionics, vol. 109, no. 3-4, pp. 311-320, 1998.

[38] R. Kanno, Y. Takeda, M. Ohya, and O. Yamamoto, "Rechargeable all solid-state cell with high copper ion conductor and copper chevrel phase," Materials Research Bulletin, vol. 22, no. 9, pp. 1283-1290, 1987.

[39] E. G. Tulsky, N. R. M. Crawford, S. A. Baudron, P. Batail, and J. R. Long, "Cluster-to-metal magnetic coupling: synthesis and characterization of 25-electron $\left[\mathrm{Re}_{6-n} \mathrm{Os}_{n} \mathrm{Se}_{8}(\mathrm{CN})_{6}\right]^{(5-n)-}(n=1,2)$ clusters and $\left\{\mathrm{Re}_{6-n} \mathrm{Os}_{n} \mathrm{Se}_{8}\left[\mathrm{CNCu}\left(\mathrm{Me}_{6} \text { tren }\right)\right]_{6}\right\}^{9+}(n=0,1,2)$ assemblies," Journal of the American Chemical Society, vol. 125, no. 50, pp. 15543-15553, 2003.

[40] D. H. Johnston, C. L. Stern, and D. F. Shriver, "Synthesis of 12metal clusters based on the $\left[\mathrm{Mo}_{6} \mathrm{Cl}_{8}\right]^{4+}$ core. X-ray structure of $(\mathrm{PPN})_{2} \mathrm{Mo}_{6} \mathrm{Cl}_{8}^{\mathrm{i}}\left\{(\mu-\mathrm{NC}) \mathrm{Mn}(\mathrm{CO})_{2} \mathrm{Cp}\right\}_{6}^{\mathrm{a}}$," Inorganic Chemistry, vol. 32, no. 23, pp. 5170-5175, 1993. 
[41] N. Prokopuk and D. F. Shriver, "A one-dimensional array of clusters: $\mathrm{Na}_{2} \mathrm{Mo}_{6} \mathrm{Cl}_{8}\left(\mathrm{O}_{2} \mathrm{CC}_{5} \mathrm{H}_{4} \mathrm{FeCp}\right)_{6} \cdot \mathrm{CH}_{3} \mathrm{OH}$," Inorganic Chemistry, vol. 36, no. 24, pp. 5609-5613, 1997.

[42] Y. V. Mironov, V. E. Federov, I. Ijjaali, and J. A. Ibers, " $\left[\left\{\left(\mathrm{Cu}(\text { en })_{2}\right\}\right)_{2} \mathrm{RE}_{4} \mathrm{TE}_{4}(\mathrm{CN})_{12}\right] \cdot 5 \mathrm{H}_{2} \mathrm{O}$ and $\left[\left\{\left(\mathrm{Cu}(\mathrm{en})_{2}\right\}\right)_{2}\right.$ $\left.\mathrm{Re}_{6} \mathrm{Te}_{8}(\mathrm{CN})_{6}\right] \cdot 5 \mathrm{H}_{2} \mathrm{O}$ : bonding of a transition-metal complex to a rhenium chalcocyanide cluster," Inorganic Chemistry, vol. 40, no. 24, pp. 6320-6323, 2001.

[43] A. Itasaka, M. Abe, T. Yoshimura, et al., "Octahedral arrangement of porphyrin moieties around hexarhenium(III) cluster cores: structure of ( $\mu 3$-Selenido)hexa-(5-(4-pyridyl)10,15,20-tritolylporphyrin)-hexarhenium(III) (2+)," Angewandte Chemie International Edition, vol. 41, no. 3, pp. 463466, 2002.

[44] S. Jin and F. J. DiSalvo, "3-D coordination network structures constructed from $\left[\mathrm{W}_{6} \mathrm{~S}_{8}(\mathrm{CN})_{6}\right]^{6-}$ anions," Chemistry of Materials, vol. 14, no. 8, pp. 3448-3457, 2002.

[45] M. V. Bennett, M. P. Shores, L. G. Beauvais, and J. R. Long, "Expansion of the porous solid $\mathrm{Na}_{2} \mathrm{Zn}_{3}\left[\mathrm{Fe}(\mathrm{CN})_{6}\right]_{2} \cdot 9 \mathrm{H}_{2} \mathrm{O}$ : enhanced ion-exchange capacity in $\mathrm{Na}_{2} \mathrm{Zn}_{3}\left[\operatorname{Re}_{6} \mathrm{Se}_{8}(\mathrm{CN})_{6}\right]_{2}$. $24 \mathrm{H}_{2} \mathrm{O}$," Journal of the American Chemical Society, vol. 122, no. 28, pp. 6664-6668, 2000.

[46] M. S. Tarasenko, N. G. Naumov, A. V. Virovets, et al., "New coordination polymers based on paramagnetic cluster anions $\left[\mathrm{Re}_{6} \mathrm{Se}_{8}(\mathrm{CN})_{6}\right]^{3-}$ and rare earth cations: the synthesis and structure of $\left.\left[\left\{\mathrm{Ln}\left(\mathrm{H}_{2} \mathrm{O}\right)_{3}\right)\right\}\left\{\mathrm{Re}_{6} \mathrm{Se}_{8}(\mathrm{CN})_{6}\right\}\right] \cdot 3.5 \mathrm{H}_{2} \mathrm{O}$," Journal of Structural Chemistry, vol. 46, supplement 1, pp. S137-S144, 2005.

[47] S. B. Artemkina, N. G. Naumov, A. V. Virovets, S. A. Gromilov, D. Fenske, and V. E. Fedorov, "New polymeric structure of rhenium octahedral chalcocyanide complex: $\mathrm{Ln}^{3+}$-derived network with one-dimensional channels," Inorganic Chemistry Communications, vol. 4, no. 8, pp. 423-426, 2001.

[48] M. S. Tarasenko, A. Yu. Ledneva, N. G. Naumov, D. Y. Naumov, and V. E. Fedorov, "Novel low dimensional cluster compounds: syntheses and crystal structures," Journal of Cluster Science, vol. 16, no. 3, pp. 353-365, 2005.

[49] Y. Kim, S.-M. Park, W. Nam, and S.-J. Kim, "Crystal structure of the two-dimensional framework $[\mathrm{Mn}(\text { salen })]_{4 n}$ $\left[\operatorname{Re}_{6} \mathrm{Te}_{8}(\mathrm{CN})_{6}\right]_{n}\left[\right.$ salen $=N, N^{\prime}$-ethylenebis(salicylideneaminato)]," Chemical Communications, no. 16, pp. 1470-1471, 2001.

[50] K. A. Brylev, Yu. V. Mironov, N. G. Naumov, V. E. Fedorov, and J. A. Ibers, "New compounds from tellurocyanide rhenium cluster anions and 3d-transition metal cations coordinated with ethylenediamine," Inorganic Chemistry, vol. 43, no. 16, pp. 4833-4838, 2004.

[51] N. G. Naumov, D. V. Soldatov, J. A. Ripmeester, S. B. Artemkina, and V. E. Federov, "Extended framework materials incorporating cyanide cluster complexes: structure of the first 3D architecture accommodating organic molecules," Chemical Communications, pp. 571-572, 2001.

[52] L. G. Beauvais, M. P. Shores, and J. R. Long, "Cyano-bridged $\mathrm{Re}_{6} \mathrm{Q}_{8}(\mathrm{Q}=\mathrm{S}, \mathrm{Se})$ cluster-cobalt(II) framework materials: versatile solid chemical sensors," Journal of the American Chemical Society, vol. 122, no. 12, pp. 2763-2772, 2000.

[53] M. P. Shores, L. G. Beauvais, and J. R. Long, " $\left[\mathrm{Cd}_{2}\right.$ $\left.\left(\mathrm{H}_{2} \mathrm{O}\right)_{4}\right]\left[\mathrm{Re}_{6} \mathrm{~S}_{8}(\mathrm{CN})_{6}\right] \cdot 14 \mathrm{H}_{2} \mathrm{O}$ : a cyano-bridged clustercluster framework solid with accessible cubelike cavities," Inorganic Chemistry, vol. 38, no. 8, pp. 1648-1649, 1999.

[54] Y. Kim, S.-M. Park, and S.-J. Kim, "Three-dimensional framework containing $\mathrm{Mn}(\text { salen })^{+}$and $\mathrm{Re}_{6} \mathrm{Se}_{8}(\mathrm{CN})_{6}^{4-}$ cluster," Inorganic Chemistry Communications, vol. 5, no. 8, pp. 592595, 2002.
[55] M. V. Bennett, L. G. Beauvais, M. P. Shores, and J. R. Long, "Expanded Prussian blue analogues incorporating $\left[\mathrm{Re}_{6} \mathrm{Se}_{8}(\mathrm{CN})_{6}\right]^{3-/ 4-}$ clusters: adjusting porosity via charge balance," Journal of the American Chemical Society, vol. 123, no. 33, pp. 8022-8032, 2001.

[56] N. G. Naumov, S. Cordier, and C. Perrin, "An extended open framework based on disordered $\left[\mathrm{Nb}_{6} \mathrm{Cl}_{9} \mathrm{O}_{3}(\mathrm{CN})_{6}\right]^{5-}$ cluster units: synthesis and crystal structure of $\mathrm{Cs}_{3} \mathrm{Mn}\left[\mathrm{Nb}_{6} \mathrm{Cl}_{9} \mathrm{O}_{3}(\mathrm{CN})_{6}\right] \cdot 0.6 \mathrm{H}_{2} \mathrm{O}$," Solid State Sciences, vol. 7, no. 12, pp. 1517-1521, 2005.

[57] L. G. Beauvais and J. R. Long, "Synthesis and characterization of prussian blue analogues incorporating the edge-bridged octahedral $\left[\mathrm{Zr}_{6} \mathrm{BCl}_{12}\right]^{2+}$ cluster core," Inorganic Chemistry, vol. 45, no. 1, pp. 236-243, 2006.

[58] S. B. Artemkina, N. G. Naumov, A. V. Virovets, and V. E. Fedorov, "3D-coordination cluster polymers $\left[\mathrm{Ln}\left(\mathrm{H}_{2} \mathrm{O}\right)_{3} \mathrm{Re}_{6} \mathrm{Te}_{8}(\mathrm{CN})_{6}\right] \cdot n \mathrm{H}_{2} \mathrm{O}\left(\mathrm{Ln}=\mathrm{La}^{3+}, \mathrm{Nd}^{3+}\right)$ : direct structural analogy with the mononuclear $\operatorname{LnM}(\mathrm{CN})_{6} \cdot n \mathrm{H}_{2} \mathrm{O}$ Family," European Journal of Inorganic Chemistry, vol. 2005, no. 1, pp. 142-146, 2005.

[59] L. G. Beauvais, M. P. Shores, and J. R. Long, "Cyano-bridged $\operatorname{Re}_{6} \mathrm{Q}_{8}(\mathrm{Q}=\mathrm{S}, \mathrm{Se})$ cluster-metal framework solids: a new class of porous materials," Chemistry of Materials, vol. 10, no. 12, pp. 3783-3786, 1998.

[60] N. G. Naumov, A. V. Virovets, M. N. Sokolov, S. B. Artemkina, and V. E. Fedorov, "A novel framework type for inorganic clusters with cyanide ligands: crystal structures of $\mathrm{Cs}_{2} \mathrm{Mn}_{3}\left[\operatorname{Re}_{6} \mathrm{Se}_{8}(\mathrm{CN})_{6}\right]_{2} \cdot 15 \mathrm{H}_{2} \mathrm{O}$ and $\left(\mathrm{H}_{3} \mathrm{O}\right)_{2} \mathrm{Co}_{3}$ $\left[\mathrm{Re}_{6} \mathrm{Se}_{8}(\mathrm{CN})_{6}\right]_{2} \cdot 14.5 \mathrm{H}_{2} \mathrm{O}$," Angewandte Chemie International Edition, vol. 37, no. 13-14, pp. 1943-1945, 1998.

[61] N. G. Naumov, A. V. Virovets, and V. E. Fedorov, "Unusually high porosity in polymeric cluster cyanides: the synthesis and crystal structure of $\left(\mathrm{H}_{3} \mathrm{O}\right)_{2} \mathrm{Zn}_{3}\left[\mathrm{Re}_{6} \mathrm{Se}_{8}(\mathrm{CN})_{6}\right]_{2} \cdot 20 \mathrm{H}_{2} \mathrm{O}$," Inorganic Chemistry Communications, vol. 3, no. 2, pp. 71-72, 2000.

[62] B. Yan, H. Zhou, and A. Lachgar, "Octahedral niobium chloride clusters as building blocks of templated prussian blue framework analogues," Inorganic Chemistry, vol. 42, no. 26, pp. 8818-8822, 2003.

[63] B. Yan, C. S. Day, and A. Lachgar, "Octahedral metal clusters as building units in a neutral layered honeycomb network, $\left[\mathrm{Zn}(\mathrm{en})_{2}\right]\left[\mathrm{Nb}_{6} \mathrm{Cl}_{12}(\mathrm{CN})_{6}\right]$," Chemical Communications, vol. 10, no. 21, pp. 2390-2391, 2004.

[64] Z. Yan, C. S. Day, and A. Lachgar, "The first coordination polymers and hydrogen bonded networks containing octahedral $\mathrm{Nb}_{6}$ clusters and alkaline earth metal complexes," Inorganic Chemistry, vol. 44, no. 13, pp. 4499-4505, 2005.

[65] H. Zhou, C. S. Day, and A. Lachgar, "Assembly of hybrid inorganic-organic materials from octahedral $\mathrm{Nb}_{6}$ clusters and metal complexes," Chemistry of Materials, vol. 16, no. 24, pp. 4870-4877, 2004.

[66] H. Zhou and A. Lachgar, "Supramolecular assemblies built of $\left[\mathrm{Nb}_{6} \mathrm{Cl}_{12}(\mathrm{CN})_{6}\right]^{4-}$ octahedral metal clusters and $[\mathrm{Mn}(\text { acacen })]^{+}$complexes," Crystal Growth and Design, vol. 6, no. 10, pp. 2384-2391, 2006.

[67] J. Zhang and A. Lachgar, "Superexpanded Prussian-blue analogue with $\left[\mathrm{Fe}(\mathrm{CN})_{6}\right]^{4-}, \quad\left[\mathrm{Nb}_{6} \mathrm{Cl}_{12}(\mathrm{CN})_{6}\right]^{4-}$, and $[\mathrm{Mn}(\text { salen })]^{+}$as building units," Journal of the American Chemical Society, vol. 129, no. 2, pp. 250-251, 2007.

[68] J.-J. Zhang, H.-J. Zhou, and A. Lachgar, "Directed assembly of cluster-based supramolecules into one-dimensional coordination polymers," Angewandte Chemie International Edition, vol. 46, no. 26, pp. 4995-4998, 2007. 
[69] H. J. Zhou and A. Lachgar, "Octahedral metal clusters $\left[\mathrm{Nb}_{6} \mathrm{Cl}_{12}(\mathrm{CN})_{6}\right]^{4-}$ as molecular building blocks: from supramolecular assemblies to coordination polymers," European Journal of Inorganic Chemistry, vol. 2007, no. 8, pp. 1053 1066, 2007.

[70] H. Zhou, K. C. Strates, M. A. Munoz, et al., "Inorganic crystal engineering through cation metathesis: one-, two-, and threedimensional cluster-based coordination polymers," Chemistry of Materials, vol. 19, no. 9, pp. 2238-2246, 2007.

[71] J. H. Yoon, J. H. Lim, H. C. Kim, and C. S. Hong, "Cyanidebridged single-molecule magnet constructed by an octacoordinated $\left[\mathrm{W}(\mathrm{CN})_{6}(\mathrm{bpy})\right]^{-}$anion," Inorganic Chemistry, vol. 45, no. 24, pp. 9613-9615, 2006.

[72] Z.-H. Ni, H.-Z. Kou, L.-F. Zhang, et al., " $\left[\mathrm{Mn}^{\mathrm{III}}(\text { salen })\right]_{6}\left[\mathrm{Fe}^{\mathrm{III}}(\mathrm{bpmb})(\mathrm{CN})_{2}\right]_{6} \cdot 7 \mathrm{H}_{2} \mathrm{O}$ : a cyanidebridged nanosized molecular wheel," Angewandte Chemie International Edition, vol. 44, no. 47, pp. 7742-7745, 2005.

[73] H. Miyasaka, H. Takahashi, T. Madanbashi, K.-I. Sugiura, R. Clerac, and H. Nojiri, "Cyano-bridged $\mathrm{Mn}_{3}^{\mathrm{III}} \mathrm{M}\left(\mathrm{M}^{\mathrm{III}}=\mathrm{Fe}, \mathrm{Cr}\right)$ complexes: synthesis, structure, and magnetic properties," Inorganic Chemistry, vol. 44, no. 17, pp. 5969-5971, 2005.

[74] M. Yuan, S. Gao, H.-L. Sun, and G. Su, "An antiferromagnetic $\mathrm{Mn}(\mathrm{III})$ chain bridged by hydrogencyanamide: $\left[\mathrm{Mn}^{\text {III }}(5-\mathrm{Brsalen})\left(\mu_{1,3}-\mathrm{NCNH}\right)\right]_{n}$," Inorganic Chemistry, vol. 43, no. 26, pp. 8221-8223, 2004.

[75] H. Miyasaka, R. Clerac, W. Wernsdorfer, et al., "A dimeric manganese(III) tetradentate Schiff base complex as a singlemolecule magnet," Angewandte Chemie International Edition, vol. 43, no. 21, pp. 2801-2805, 2004.

[76] J. M. Ready and E. N. Jacobsen, "Highly active oligomeric (salen)Co catalysts for asymmetric epoxide ring-opening reactions," Journal of the American Chemical Society, vol. 123, no. 11, pp. 2687-2688, 2001.

[77] H. Li, Z. J. Zhong, C.-Y. Duan, X.-Z. You, T. C. W. Mak, and $\mathrm{B}$. Wu, "Synthesis and crystal structure of a manganese(III) complex with the tetradentate schiff base N, $N^{\prime}$-ethylenebis(salicylideneiminato)," Journal of Coordination Chemistry, vol. 41, no. 3, pp. 183-189, 1997.

[78] M. Suzuki, T. Ishikawa, A. Harada, S. Ohba, M. Sakamoto, and Y. Nishida, "Chemical mechanism of dioxygen activation by manganese(III) Schiff base compound in the presence of aliphatic aldehydes," Polyhedron, vol. 16, no. 15, pp. 25532561, 1997.

[79] J. G. Converse and R. E. McCarley, "Chemistry of polynuclear metal halides. VI. Magnetic susceptibility studies of some niobium and tantalum halide cluster derivatives," Inorganic Chemistry, vol. 9, no. 6, pp. 1361-1366, 1970.

[80] O. Kahn, Molecular Magnetism, Wiley-VCH, New York, NY, USA, 1993.

[81] GADDS V4.1.14, "General Area Detector Diffraction System Program for Instrument Control and Data Collection," BRUKER AXS Inc., 5465 East Cheryl Parkway, Madison, WI 53711-5373 USA.

[82] EVA V8.0, "Graphics Program for 2-dimensional Data evaluation and Presentation," BRUKER AXS Inc., 5465 East Cheryl Parkway, Madison, WI 53711-5373 USA.

[83] A. Panja, N. Shaikh, M. Ali, P. Vojtisek, and P. Banerjee, "Structural characterization of a new manganese(III)salen complex $\left[\mathrm{H}_{2}\right.$ salen $=\mathrm{N}, \mathrm{N}^{\prime}$-bis(salicylidene)ethane-1,2diamine] and study of its electron transfer kinetics with hydroquinone and catechol," Polyhedron, vol. 22, no. 9, pp. 1191-1198, 2003.
[84] Z. P. Zheng, T. G. Gray, and R. H. Holm, "Synthesis and structures of solvated monoclusters and bridged di- and triclusters based on the cubic building block $\left[\operatorname{Re}_{6}\left(\mu_{3}-\mathrm{Se}\right)_{8}\right]^{2+}$, Inorganic Chemistry, vol. 38, no. 21, pp. 4888-4895, 1999.

[85] H. D. Selby, P. Orto, M. D. Carducci, and Z. P. Zheng, "Novel concentration-driven structural interconversion in shapespecific solids supported by the octahedral $\left[\operatorname{Re}_{6}\left(\mu_{3}-\mathrm{Se}\right)_{8}\right]^{2+}$ cluster core," Inorganic Chemistry, vol. 41, no. 24, pp. 61756177, 2002.

[86] B. K. Roland, H. D. Selby, M. D. Carducci, and Z. P. Zheng, "Built to order: molecular tinkertoys from the $\left[\operatorname{Re}_{6}\left(\mu_{3}-\mathrm{Se}\right)_{8}\right]^{2+}$ clusters," Journal of the American Chemical Society, vol. 124, no. 13, pp. 3222-3223, 2002.

[87] B. K. Roland, W. H. Flora, H. D. Selby, N. R. Armstrong, and Z. Zheng, "Dendritic arrays of $\left[\operatorname{Re}_{6}\left(\mu_{3}-\mathrm{Se}\right)_{8}\right]^{2+}$ core-containing clusters: exploratory synthesis and electrochemical studies," Journal of the American Chemical Society, vol. 128, no. 20, pp. 6620-6625, 2006.

[88] H. Hanika-Heidl, S. E. H. Etaiw, M. S. Ibrahim, A. S. Bader ElDin, and R. D. Fischer, "New supramolecular organotin(IV)/copper(I) cyanides containing the unique $\left\{\mathrm{Cu}^{\mathrm{I}}(\mu-\mathrm{CN})_{2}\right\}$ building block," Journal of Organometallic Chemistry, vol. 684, no. 1-2, pp. 329-337, 2003.

[89] T. Soma, H. Yuge, and T. Iwamoto, "Threedimensional interpenetrating double and triple framework structures in $\left[\mathrm{Cd}(\mathrm{bpy})_{2}\left\{\mathrm{Ag}(\mathrm{CN})_{2}\right\}_{2}\right]$ and $\left[\mathrm{Cd}(\right.$ pyrz $\left.)\left\{\mathrm{Ag}_{2}(\mathrm{CN})_{3}\right\}\left\{\mathrm{Ag}(\mathrm{CN})_{2}\right\}\right]$," Angewandte Chemie International Edition, vol. 33, no. 15-16, pp. 1665-1666, 1994.

[90] V. Niel, M. C. Munoz, A. B. Gaspar, A. Galet, G. Levchenko, and J. A. Real, "Thermal-, pressure-, and light-induced spin transition in novel cyanide-bridged FeII-AgI bimetallic compounds with three-dimensional interpenetrating double structures $\left\{\mathrm{Fe}^{\mathrm{II}} \mathrm{L}_{\mathrm{x}}\left[\mathrm{Ag}(\mathrm{CN})_{2}\right]_{2}\right\} \cdot \mathrm{G}$," Chemistry, vol. 8, no. 11, pp. 2446-2453, 2002.

[91] B. F. Abrahams, M. J. Hardie, B. F. Hoskins, R. Robson, and E. E. Sutherland, Chemical Communications, pp. 1049-1050, 1994.

[92] H.-Z. Kou, Y.-B. Jiang, B. C. Zhou, and R.-J. Wang, "Cyanobridged 2D CuII-CrIII coordination polymers: structural evidence for formation of a polymeric macrocyclic metallic compound," Inorganic Chemistry, vol. 43, no. 10, pp. 32713276, 2004.

[93] S. R. Batten, B. F. Hoskins, and R. Robson, "Two interpenetrating 3D networks which generate spacious sealed-off compartments enclosing of the order of 20 solvent molecules in the structures of $\mathrm{Zn}(\mathrm{CN})\left(\mathrm{NO}_{3}\right)(\mathrm{tpt}) 2 / 3$.solv (tpt $=2,4,6$-tri(4-pyridyl)1,3,5-triazine, solv $=$.apprx.3/4C2 $\mathrm{H} 2 \mathrm{Cl} 4$. cntdot. $3 / 4 \mathrm{CH}_{3} \mathrm{OH}$ or .apprx. $3 / 2 \mathrm{CHCl}_{3}$. cntdot. $\left.1 / 3 \mathrm{CH}_{3} \mathrm{OH}\right)$," Journal of the American Chemical Society, vol. 117, no. 19, pp. 5385-5386, 1995.

[94] H. Weitzel, "Ikistallstrukturverfeinerungen von Wolframiten und columbiten," Zeitschrift für Kristallographie, vol. 144, pp. 238-258, 1976.

[95] L. M. Kuznetsov, A. N. Tsvigunov, and K. P. Burdina, Geokhimiya, p. 254, 1979.

[96] A. Nägele, J. Glaser, and H.-J. Meyer, "New syntheses, new structure refinement, electronic structure, and magnetism," Zeitschrift für Anorganische und Allgemeine Chemie, vol. 627, no. 2, pp. 244-249, 2001.

[97] J. G. Converse and R. E. McCarley, "Chemistry of polynuclear metal halides. VI. Magnetic susceptibility studies of some niobium and tantalum halide cluster derivatives," Inorganic Chemistry, vol. 9, no. 6, pp. 1361-1366, 1970. 
[98] Q. Shi, R. Cao, X. Li, J. H. Luo, M. C. Hong, and Z. N. Chen, "Syntheses, structures, electrochemistry and magnetic properties of chain-like dicyanamide manganese(III) and iron(III) complexes with salen ligand," New Journal of Chemistry, vol. 26, pp. 1397-1401, 2002.

[99] A. Panja, N. Shaikh, P. V. Vojtisek, S. Gao, and P. Banerjee, "Synthesis, crystal structures and magnetic properties of $1 \mathrm{D}$ polymeric $\left[\mathrm{Mn}^{\mathrm{III}}\right.$ (salen) $\left.\mathrm{N}_{3}\right]$ and $\left[\mathrm{Mn}^{\mathrm{III}}\right.$ (salen) $\left.\mathrm{Ag}(\mathrm{CN})_{2}\right]$ complexes," New Journal of Chemistry, vol. 26, no. 8, pp. 10251028, 2002. 

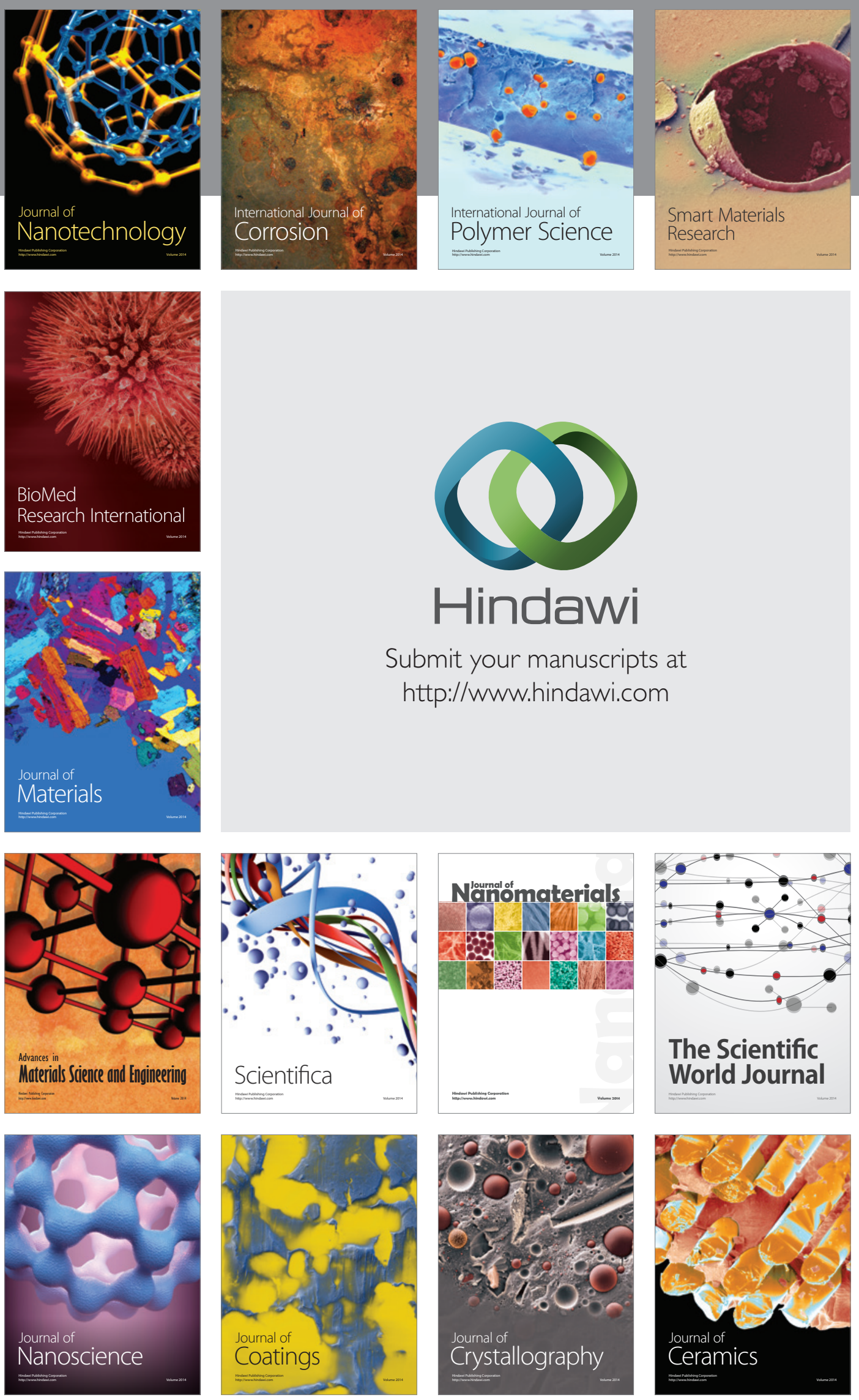

The Scientific World Journal

Submit your manuscripts at

http://www.hindawi.com

\section{World Journal}

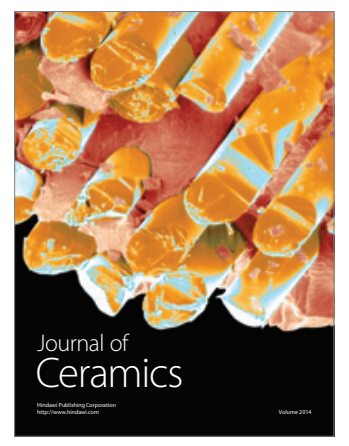

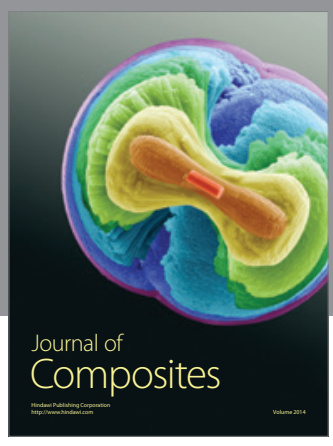
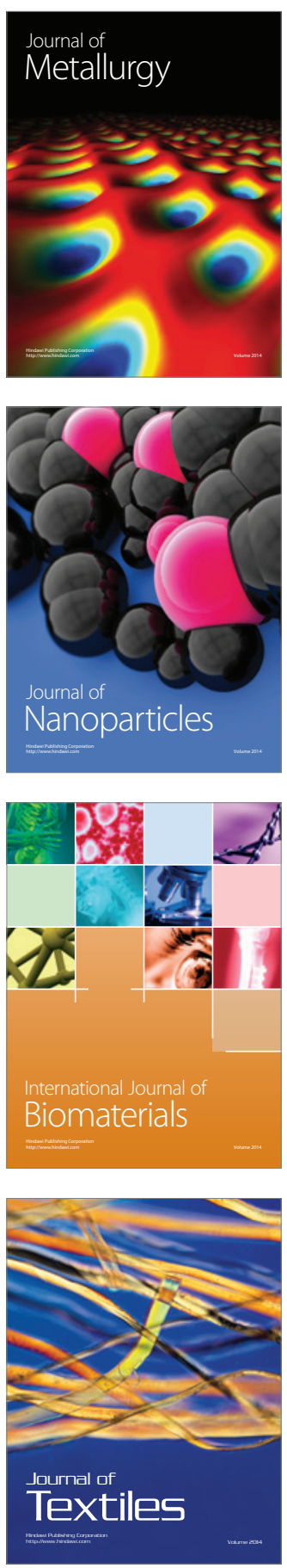